\title{
Adolescent pre-exposure prophylaxis for HIV prevention: current perspectives
}

This article was published in the following Dove Press journal:

Adolescent Health, Medicine and Therapeutics

\section{Daisy Maria Machado' \\ Alexandre Machado de Sant'Anna Carvalho ${ }^{2}$ Rachel Riera ${ }^{3}$}

'Disciplina de Infectologia Pediátrica, Departamento de Pediatria, Escola Paulista de Medicina, Universidade Federal de São Paulo, São Paulo, ${ }^{2}$ Universidade Federal do Rio de Janeiro, Rio de Janeiro, ${ }^{3}$ Disciplina de Medicina Baseada em Evidências, Departamento de Medicina, Escola Paulista de Medicina, Universidade Federal de São Paulo, São Paulo, Brazil
Correspondence: Daisy Maria Machado Disciplina de Infectologia Pediátrica, Departamento de Pediatria, Escola Paulista de Medicina, Universidade Federal de São Paulo, Rua Pedro de Toledo \# 928, Vila Clementino, CEP 04039-002 São Paulo, Brazil Tel +55 I I 5576 4848x I 7007 Email daisymmachado@gmail.com

\begin{abstract}
Adolescents are a critical population that is disproportionately impacted by the HIV epidemic. More than 2 million adolescents between the age group of 10 and 19 years are living with HIV, and millions are at risk of infection. HIV risks are considerably higher among girls, especially in high-prevalence settings such as eastern and southern Africa. In addition to girls, there are other vulnerable adolescent subgroups, such as teenagers, who use intravenous (IV) drugs, gay and bisexual boys, transgender youth, male sex workers, and people who fall into more than one of these categories. Pre-exposure prophylaxis (PrEP) is a new intervention for people at high risk for acquiring HIV, with an estimated HIV incidence of $>3 \%$. Recent data from trials show evidence of the efficacy of PrEP as a powerful HIV prevention tool in high-risk populations, including men who have sex with men, HIV-1-serodiscordant heterosexual couples, and IV drug users. The reported efficacy in those trials of the daily use of oral tenofovir, alone or in combination with emtricitabine, to prevent HIV infection ranged from $44 \%$ to $75 \%$ and was heavily dependent on adherence. Despite the proven efficacy of PrEP in adult trials, concerns remain about its feasibility in real-life scenarios due to stigma, cost, and limited clinician experience with PrEP delivery. Recent studies are attempting to expand the inquiry into the efficacy of such HIV prophylaxis approaches in adolescent populations, but there are still many gaps in knowledge, and no country has yet approved it for use with adolescents. The aim of this review was to identify and summarize the evidence from studies on PrEP for adolescents. We have compiled and reviewed published studies focusing on safety, feasibility, adherence to therapeutics, self-perception, and legal issues related to PrEP in people aged between 10 and 24 years. Keywords: HIV prevention, pre-exposure prophylaxis (PrEP), adolescents, youth
\end{abstract}

\section{Introduction}

Adolescents are a critical population that is disproportionately impacted by the HIV epidemic. AIDS is the leading cause of death among adolescents in sub-Saharan Africa and is the second cause of mortality among youth worldwide. ${ }^{1}$ Over 2 million adolescents between the age group of 10 and 19 years are living with HIV, and millions more are at risk of infection every year. ${ }^{2}$

Due to fundamental neurological, psychological, and behavioral changes that take place during adolescence, ${ }^{3}$ this group is considered highly vulnerable to contracting HIV. $^{4,5}$ Infection risks are considerably higher among girls, especially in high-prevalence settings such as eastern and southern Africa. Due to preexisting, gender-based inequalities such as exclusion and sexual violence, this subgroup is disproportionately affected by HIV. In 2013, two-thirds of new HIV infections reported in people between the age group of 15 and 19 years were adolescent girls, particularly in sub-Saharan Africa. ${ }^{6}$ 
Furthermore, besides young women, there are other youth populations that exhibit distinct sociobehavioral patterns that increase their risk to contracting the virus, such as intravenous drug users, gay and bisexual-identifying teenagers, adolescent sex workers, and those who belong to multiple risk categories. Their public health outcomes can be influenced by evidence-based primary preventive strategies, so the focus should be on them.

Goal \#3 of the United Nations' "Sustainable Development Goals" (SDG3) - to ensure healthy lives and promote wellbeing for all ages - requires as a target that by 2030 there should be an end to the epidemic of AIDS. To achieve this ambitious goal, each age group, population, and geographical location will require specific and flexible strategies. ${ }^{7}$

\section{Pre-exposure prophylaxis (PrEP) as an HIV prevention strategy}

PrEP is a new intervention for people at high risk to contracting HIV, with an estimated HIV incidence of $>3 \%$, based on the use of oral antiretroviral medications to help prevent the infection. A daily use of two combined antiretroviral drugs (tenofovir disoproxil fumarate [TDF]/emtricitabine [FTC]) was approved as PrEP in 2012, sold under the name Truvada ${ }^{\circledR 8}$.

Recent data from clinical trials have demonstrated the efficacy of PrEP as a powerful HIV prevention tool in some high-risk populations including men who have sex with men, ${ }^{9}$ HIV-1-serodiscordant heterosexual couples, ${ }^{10}$ and intravenous drug users. ${ }^{11}$ PrEP effectively reduced HIV infection in four of six trials conducted with the adult population. ${ }^{9-11}$ The reported efficacy in those randomized trials using TDF as a single agent or in combination with FTC to prevent HIV infection ranged from $44 \%$ to $75 \%$ and was heavily dependent on patient adherence (Table 1).

The Phase III randomized clinical trial PrEP initiative (iPrEx) highlighted the importance of adherence with overall protective efficacy of $44 \%$, but as high as $92 \%$ in those with detectable drug levels. ${ }^{9}$ Two trials (the FEMPrEP ${ }^{12}$ and
VOICE ${ }^{13}$ ) showed no significant protective effect in women, yet less than $30 \%$ adhered to the prescribed intervention, as observed through drug concentration analysis.

Despite the proven efficacy of PrEP in adult trials, there are concerns about real-life feasibility due to several barriers including stigma, cost, and limited experience in PrEP delivery by HIV providers. However, some of these concerns abated after demonstration projects showed high clinical effectiveness (>80\%). ${ }^{14,15}$

Recent studies are attempting to expand the investigation into the efficacy of such HIV prophylaxis approaches in adolescent populations. However, there are still many knowledge gaps, and no country has yet approved it for use with adolescents. Guidelines have recommended the use of PrEP as part of prevention for persons at substantial risk for HIV infection without limiting the recommendations to specific populations. ${ }^{16}$

The aim of this review was to identify and summarize the evidence from studies on PrEP for adolescents. We mapped published studies focusing on the safety, feasibility, acceptability, adherence to therapeutics, self-perception, and legal issues related to PrEP in people aged between 10 and 24 years.

\section{Criteria for considering studies for this review Type of studies}

We considered the following study designs for inclusion:

1. Primary studies, such as randomized, quasi-randomized, and nonrandomized clinical trials, longitudinal observational (historical cohorts, prospective cohorts, case-control, and before-and-after studies), analytic cross-sectional studies, and non-comparative studies (case and series reports or single experimental cohorts).

2. Secondary studies, including systematic reviews, guidelines, or economic evaluations. We did not consider narrative reviews, case reports, comments, or editorials.

Table I Clinical trials of PrEP in the population at risk of HIV infection

\begin{tabular}{|c|c|c|c|c|}
\hline Study & Population & Age & $\begin{array}{l}\text { Efficacy of TDF or } \\
\text { TDF/FTC compared } \\
\text { with placebo (\%) }\end{array}$ & Adherence (\%) \\
\hline Partners PrEP (TDF + FTC or TDF) & Heterosexual men and women & 18 years or older & 75 & 82 \\
\hline Botswana TDF2 (TDF + FTC) & Heterosexual men and women & 18 years or older & 62 & 79 \\
\hline Bangkok (TDF) & Drug users & 18 years or older & 49 & 67 \\
\hline ¡PrEx (TDF + FTC) & Men who have sex with men & 18 years or older & 44 & 51 \\
\hline FemPrEP (TDF + FTC) & African women & I8-35 years; mean: 24.2 years & 6 & 26 \\
\hline VOICE (TDF + FTC or TDF gel) & Women & I8-45 years; mean: 25.3 years & -4.2 & 29 \\
\hline
\end{tabular}

Abbreviations: FTC, emtricitabine; PrEP, pre-exposure prophylaxis; iPrEx, PrEP initiative; TDF, tenofovir disoproxil fumarate. 


\section{Type of participants}

Although the focus was primarily on the second decade of life, in some cases data on youth or young people were included. This inclusion is generally due to data being aggregated in ways that did not distinguish adolescent years specifically.

\section{Defining overlapping terms "adolescents," "youth," and "young people"}

The World Health Organization (WHO) defines adolescent as those people between 10 and 19 years of age. The United Nations define youth as $15-24$ years, and the term "young people" is used by WHO and others to combine adolescents and youth. ${ }^{17}$

\section{Outcomes of interest}

We considered all effectiveness and safety outcomes for therapeutic studies addressing PrEP use. For all studies, we collected data linking PrEP use to adherence, adolescent self-perception, satisfaction, health care provider attitudes related to youth, and legal issues.

\section{Strategy for searching studies}

We conducted a systematic search of studies on 23 and 24 January 2017 in the following databases: MEDLINE (via PubMed, from 1946), EMBASE (via Elsevier, from 1974), Cochrane Library (via Wiley, issue 1, 2017), Literatura LatinoAmericana em Ciências da Saúde e do Caribe [Latin America and Caribbean Health Sciences Literature] (LILACS; via Biblioteca Virtual em Saúde [BVS], from 1966), and ADOLEC (via BVS). We also searched for ongoing or unpublished trials in the US National Institutes of Health Ongoing Trials Register (www.clinicaltrials.gov) and the WHO International Clinical Trials Registry Platform (ICTRP; http://apps.who.int/ trialsearch). The search strategies are available as Appendix 1.

\section{Study selection}

Two reviewers (DMM and RR) independently assessed titles and abstracts from all records retrieved by the literature search for eligibility according to the inclusion criteria. Studies selected at this first stage were then evaluated in its full text to confirm eligibility. Disagreements between reviewers were resolved using consensus-based models for decision making. The selection process was performed using the Rayyan platform. ${ }^{18}$

\section{Data extraction and presentation of findings}

The authors extracted the data on publication, methods, and results of included studies. The findings are summarized in Tables 1 and 2 using a narrative approach.
The search strategies retrieved 521 records. The PRISMA diagram is shown in Figure 1.

From the 44 studies initially retrieved by the search strategy, 31 were excluded, due to inclusion of participants older than 25 years, without depicting young people separately in the analysis. Of the 13 selected studies, there were six registered clinical trials, and two of which evaluated safety, feasibility, and the acceptability of daily oral TDF/FTC $\left(\right.$ Truvada $^{\circledR}$ ) specifically among adolescents.

The Adolescent Medicine Trials Network [ATN] protocol 113 (NCT01769456) ${ }^{19}$ recruited participants from six study sites in the USA, and the CHAMPS PillPlus (NCT02213328), ${ }^{20}$ in two peri-urban settings in South Africa. Other selected trials included participants up to 24 years of age combining behavioral HIV prevention interventions and oral PrEP. The trials and other studies in this review are summarized in Table 2. They also addressed several domains, including feasibility, medical adherence, the acceptability of oral daily TDF or TDF/FTC, patterns of PrEP use, patterns of sexual risk behavior, risk compensation, as well as cognitive and emotional processes in response to using PrEP. The ATN 082 study compared proven behavioral HIV prevention interventions (Many Men, Many Voices [3MV]) alone and in combination with PrEP or placebo. ${ }^{21}$

There are three selected trials that are still ongoing, with complete results unavailable as of yet. One of which is evaluating the differences in adherence to PrEP with or without the use of short message service (SMS) reminders (NCT02915367). ${ }^{22}$ The HPTN 082 trial is comparing standard adherence support versus enhanced counseling based on feedback from observed drug levels. ${ }^{23}$ Besides, qualitative research is availing the factors influencing PrEP initiation and adherence.

The NCT0281024924 has a qualitative design aims to identify and understand African American young men who have sex with men (YMSM)'s cognitive and emotional processes in response to using PrEP to reduce their risk for HIV, as well as to identify what factors influence African American YMSM's likely use of PrEP.

The systematic review retrieved studies' referencing values and preferences among populations that might benefit from PrEP, as well as health care providers who may prescribe PrEP. Of the 76 included studies, 71 addressed adult populations. Just five studies focused on adolescent girls and young women. ${ }^{25}$ The substudy of Crew 450, an ongoing longitudinal cohort study, describes PrEP interests among racially and ethnically diverse YMSM aged 16-20 years, utilizing a PrEP interest scale with a score of the likelihood of using PrEP. ${ }^{26}$

Fisher et $\mathrm{al}^{27}$ provided empirical data on sexual and gender minority youth (SGMY) self-consent that can assist 
Table 2 Summary of the included studies

\begin{tabular}{|c|c|c|c|c|c|}
\hline Study/country & Type of study & Population/age & Aims/outcomes & Description & Results \\
\hline $\begin{array}{l}\text { Project PrEPare } \\
\text { ATN I I3 } \\
\text { (NCT0I769456) } \\
\text { and ATN II0 } \\
\text { (NCTOI772823) } \\
\text { Country: USA (six } \\
\text { study sites: Boston, } \\
\text { Chicago, Los } \\
\text { Angeles, Memphis, } \\
\text { New Orleans, and } \\
\text { Philadelphia) }\end{array}$ & $\begin{array}{l}\text { Open-label } \\
\text { demonstration } \\
\text { project and } \\
\text { Phase II safety } \\
\text { study } \\
\text { Situation: } \\
\text { completed }\end{array}$ & $\begin{array}{l}\text { Enrolled: } 78 \\
\text { young HIV- } \\
\text { negative MSM } \\
35 \% \text { Black/ } \\
\text { African American } \\
\text { 45\% Latino/ } \\
\text { Hispanic: } \\
\text { I5-17 years } \\
\text { (ATN II I3); } \\
\text { I8-22 years } \\
\text { (ATN I I0) }\end{array}$ & $\begin{array}{l}\text { To evaluate: } \\
\text { Safety of daily oral } \\
\text { TDF/FTC (Truvada }{ }^{\circledR} \text { ) } \\
\text { Patterns of use } \\
\text { Rates of adherence } \\
\text { Patterns of sexual } \\
\text { risk behavior }\end{array}$ & $\begin{array}{l}\text { Study subjects engaged in } \\
\text { a behavioral risk-reduction } \\
\text { intervention before PrEP. } \\
\text { Monthly visits for the first } \\
12 \text { weeks of study. } \\
\text { Quarterly visits thereafter } \\
\text { until } 48 \text { weeks of study }\end{array}$ & $\begin{array}{l}\text { Acceptability of PrEP } \\
\text { was high: }-56 \% \text { with TDF } \\
\text { diphosphate drug levels } \\
\text { consistent with } \geq 4 \text { pills per } \\
\text { week (at week } 24 \text { ) and } 34 \% \\
\text { at week } 48 \text {. } \\
\text { Noticeable drop-off } \\
\text { occurring at week } 24\end{array}$ \\
\hline $\begin{array}{l}\text { Project PrEPare } \\
\text { ATN 082 } \\
\text { (NCT0I033942) } \\
\text { Country: USA (six } \\
\text { study sites: Boston, } \\
\text { Chicago, Los } \\
\text { Angeles, Memphis, } \\
\text { New Orleans, and } \\
\text { Philadelphia) } \\
\text { Hosek et al }{ }^{21}\end{array}$ & $\begin{array}{l}\text { Demonstration } \\
\text { project and } \\
\text { Phase II safety } \\
\text { study } \\
\text { Randomized } \\
\text { three-arm } \\
\text { design } \\
\text { Completed }\end{array}$ & $\begin{array}{l}\text { Enrolled: } 68 \\
\text { youth (mean age } \\
=19.97 \text { years; } \\
53 \% \text { African } \\
\text { American, } 40 \% \\
\text { Latino) } \\
\text { Randomized: } 58 \\
\text { (18-22 years) }\end{array}$ & $\begin{array}{l}\text { To compare an } \\
\text { efficacious behavioral } \\
\text { HIV prevention } \\
\text { intervention ( } 3 \mathrm{MV} \text { ) } \\
\text { alone, } 3 \mathrm{MV} \text { combined } \\
\text { with PrEP (TDF/FTC), } \\
\text { and } 3 \mathrm{MV} \text { combined } \\
\text { with placebo. } \\
\text { Measures: } \\
\text { Feasibility } \\
\text { Acceptability of study } \\
\text { design } \\
\text { Adherence to study } \\
\text { drug } \\
\text { Sexual behaviors } \\
\text { Risk compensation }\end{array}$ & $\begin{array}{l}\text { 3MV intervention: } \\
\text { conducted as a 2-day } \\
\text { seminar throughout } \\
\text { centrally located } \\
\text { communities in Chicago } \\
\text { with approximately eight } \\
\text { participants per session. } \\
\text { After 3MV, study } \\
\text { participants were } \\
\text { randomized in blocks of } \\
\text { six within each site to } \\
\text { one of three study arms: } \\
\text { I) daily combo FTC and } \\
\text { TDF as PrEP, 2) placebo } \\
\text { pill control (with HIV } \\
\text { behavioral intervention), } \\
\text { or (3) "no pill" control } \\
\text { (subjects receive HIV } \\
\text { behavioral intervention but } \\
\text { no pills) }\end{array}$ & $\begin{array}{l}\text { The feasibility of enrolling } \\
\text { at-risk youth, particularly } \\
\text { YMSM of color has been } \\
\text { demonstrated. } \\
\text { The acceptability of the } \\
\text { group intervention along } \\
\text { with counseling and testing } \\
\text { was high. } \\
\text { Self-reported medication } \\
\text { adherence and } \\
\text { corresponding plasma drug } \\
\text { concentrations were low. } \\
\text { Behavioral disinhibition was } \\
\text { not seen. } \\
\text { Decrease in sexual risk } \\
\text { behavior was seen over time }\end{array}$ \\
\hline $\begin{array}{l}\text { CHAMPS PillsPlus } \\
\text { (clinical trial: } \\
\text { NCT022 I3328) } \\
\text { Country: } \\
\text { South Africa } \\
\text { (Johannesburg and } \\
\text { Cape Town) }\end{array}$ & $\begin{array}{l}\text { Prospective, } \\
\text { open-label } \\
\text { Situation: active, } \\
\text { not recruiting }\end{array}$ & $\begin{array}{l}\text { Enrolled: } \\
\text { HIV-negative } \\
\text { adolescents } \\
98 \text { female } \\
50 \text { male } \\
15-19 \text { years } \\
\text { Median age } \\
\text { of } 18 \text { years } \\
\text { (17-19 years) }\end{array}$ & $\begin{array}{l}\text { To evaluate: } \\
\text { Safety, feasibility, } \\
\text { acceptability of } \\
\text { daily oral TDF/FTC } \\
\left(\text { Truvada }^{\circledR}\right)\end{array}$ & $\begin{array}{l}\text { Daily oral PrEP as part of } \\
\text { an HIV prevention package } \\
\text { that included condoms } \\
\text { and STI screening and } \\
\text { treatment. } \\
\text { Adherence support using } \\
\text { SMS, adherence clubs, } \\
\text { real-time feedback on drug } \\
\text { levels }\end{array}$ & $\begin{array}{l}\text { Estimated date for final data } \\
\text { collection date for primary } \\
\text { outcome measure: August } \\
2017\end{array}$ \\
\hline $\begin{array}{l}\text { HPTN } 082 \\
\text { (clinical trial: } \\
\text { NCT01033942) } \\
\text { Country: South } \\
\text { Africa and } \\
\text { Zimbabwe }\end{array}$ & $\begin{array}{l}\text { Randomized } \\
\text { multisite } \\
\text { prospective } \\
\text { study } \\
\text { Situation: } \\
\text { ongoing }\end{array}$ & $\begin{array}{l}\text { Enrolled: } \\
\text { adolescent } \\
\text { and young } \\
\text { adult women } \\
\text { (16-25 years) }\end{array}$ & $\begin{array}{l}\text { To assess the } \\
\text { acceptance } \\
\text { rate, adherence, } \\
\text { acceptability, and } \\
\text { continuation of oral } \\
\text { PrEP among young } \\
\text { Southern African } \\
\text { women }\end{array}$ & $\begin{array}{l}\text { Standard adherence } \\
\text { support versus enhanced } \\
\text { counseling based on } \\
\text { feedback from observed } \\
\text { drug levels in the first } \\
2 \text { months after PrEP } \\
\text { initiation. } \\
\text { Qualitative research about } \\
\text { factors influencing PrEP } \\
\text { initiation and adherence } \\
\text { (for those who initially } \\
\text { declined PrEP) }\end{array}$ & Ongoing \\
\hline
\end{tabular}


Table 2 (Continued)

\begin{tabular}{|c|c|c|c|c|c|}
\hline Study/country & Type of study & Population/age & Aims/outcomes & Description & Results \\
\hline $\begin{array}{l}\text { Clinical trial } \\
\text { (NCT029/5367) } \\
\text { Country: Kenya }\end{array}$ & $\begin{array}{l}\text { Interventional, } \\
\text { randomized, } \\
\text { open-label }\end{array}$ & $\begin{array}{l}\text { Young women } \\
\text { (18-24 years) }\end{array}$ & $\begin{array}{l}\text { I) To evaluate the } \\
\text { difference in adherence } \\
\text { to PrEP by the study } \\
\text { arm: SMS reminders } \\
\text { versus no reminders } \\
\text { 2) Acceptability } \\
\text { 3) Risk perception }\end{array}$ & $\begin{array}{l}\text { Intervention: behavioral. } \\
\text { Adherence Wisepill data } \\
\text { and TDF concentration on } \\
\text { dried blood spots }\end{array}$ & Ongoing \\
\hline $\begin{array}{l}\text { Clinical trial } \\
\text { (NCT028I0249) } \\
\text { Country: USA }\end{array}$ & $\begin{array}{l}\text { Observational, } \\
\text { with a } \\
\text { qualitative } \\
\text { design }\end{array}$ & $\begin{array}{l}\text { 20-30 African } \\
\text { American YMSM } \\
\text { aged } 16-24 \text { years }\end{array}$ & $\begin{array}{l}\text { I) To identify and } \\
\text { understand African } \\
\text { American YMSM's } \\
\text { cognitive and emotional } \\
\text { processes in response } \\
\text { to using PrEP to reduce } \\
\text { their risk for HIV } \\
\text { 2) To identify what } \\
\text { factors (sociocultural, } \\
\text { individual, experiences } \\
\text { in health care, } \\
\text { socioeconomic) } \\
\text { influence African } \\
\text { American YMSM's likely } \\
\text { use of PrEP }\end{array}$ & Individual interviews & Ongoing \\
\hline Koechlin et $\mathrm{al}^{25}$ & $\begin{array}{l}\text { Systematic } \\
\text { review }\end{array}$ & $\begin{array}{l}78 \text { studies } \\
\text { evaluated } \\
\text { hypothetical use } \\
\text { of PrEP (five } \\
\text { studies were } \\
\text { conducted among } \\
\text { "adolescent } \\
\text { girls_and young } \\
\text { women." } \\
26 \text { studies } \\
\text { included } \\
\text { individuals who } \\
\text { actually took } \\
\text { PrEP or placebo }\end{array}$ & $\begin{array}{l}\text { To describe the } \\
\text { evidence about values } \\
\text { and preferences among } \\
\text { populations that might } \\
\text { benefit from PrEP and } \\
\text { among health care } \\
\text { providers who may } \\
\text { prescribe PrEP }\end{array}$ & $\begin{array}{l}\text { Three electronic databases } \\
\text { of articles and HIV-related } \\
\text { conference abstracts } \\
\text { (January 1990-April 2015) } \\
\text { Type of studies: } \\
68 \text { quantitative } \\
24 \text { qualitative } \\
12 \text { mixed methods }\end{array}$ & $\begin{array}{l}\text { Participants showed strong } \\
\text { interest in PrEP (aged } \\
\text { I4-24 years). } \\
\text { They appreciated the } \\
\text { "privacy" of a pill; some girls } \\
\text { expressed hesitation with } \\
\text { regard to PrEP. } \\
\text { Participants would be willing } \\
\text { to take PrEP if it was free. } \\
\text { One study showed } 20 \% \text { of } \\
\text { young women expecting to } \\
\text { use condoms less frequently } \\
\text { if they took PrEP }\end{array}$ \\
\hline $\begin{array}{l}\text { Substudy of Crew } \\
450 \text { (an ongoing } \\
\text { longitudinal cohort } \\
\text { study, } \mathrm{N}=45 \text { I } \\
\text { YMSM); Chicago, } \\
\text { USA }\end{array}$ & $\begin{array}{l}\text { Observational, } \\
\text { cross-sectional }\end{array}$ & $\begin{array}{l}\text { YMSM aged } \\
16-20 \text { years } \\
N=184\end{array}$ & $\begin{array}{l}\text { To describe PrEP } \\
\text { interests among } \\
\text { racially and ethnically } \\
\text { diverse YMSM aged } \\
\text { I6-20 years using a } \\
\text { new measure that may } \\
\text { have utility in the future } \\
\text { studies }\end{array}$ & $\begin{array}{l}\text { Computer-assisted } \\
\text { self-interview with audio } \\
\text { instructions. } \\
\text { PrEP interest scale with a } \\
\text { score of the likelihood of } \\
\text { using PrEP }\end{array}$ & $\begin{array}{l}\text { Participants with better } \\
\text { HIV knowledge had higher } \\
\text { interests in PrEP. } \\
\text { Higher level of education } \\
\text { was related to an increased } \\
\text { likelihood of taking PrEP. } \\
\text { No relationship between } \\
\text { most of the reported risk } \\
\text { behaviors and mean PrEP } \\
\text { interest scores. } \\
\text { Indirectly proportional } \\
\text { relationship between } \\
\text { unprotected anal } \\
\text { intercourse with PrEP } \\
\text { interest }\end{array}$ \\
\hline
\end{tabular}

(Continued) 
Table 2 (Continued)

\begin{tabular}{|c|c|c|c|c|c|}
\hline Study/country & Type of study & Population/age & Aims/outcomes & Description & Results \\
\hline $\begin{array}{l}\text { Fisher et } \mathrm{a}^{27} \\
\text { NY, USA }\end{array}$ & $\begin{array}{l}\text { Qualitative } \\
\text { study, using } \\
\text { a Web-based } \\
\text { qualitative/ } \\
\text { mixed methods } \\
\text { analysis program }\end{array}$ & $\begin{array}{l}\text { Enrolled: } 60 \\
\text { sexually active } \\
\text { SGMY I4- } \\
17 \text { years }\end{array}$ & $\begin{array}{l}\text { To provide empirical } \\
\text { data on SGMY self- } \\
\text { consent that can assist } \\
\text { IRBs on strategies to } \\
\text { increase their research } \\
\text { participation }\end{array}$ & $\begin{array}{l}\text { Online survey and } \\
\text { asynchronous focus group } \\
\text { questions after watching a } \\
\text { video about PrEP. } \\
\text { Discussions addressed: } \\
\text { guardian permission, } \\
\text { random assignment, } \\
\text { privacy concerns, and PrEP } \\
\text { medication adherence }\end{array}$ & $\begin{array}{l}\text { Adolescents have the ability } \\
\text { to self-consent as compared } \\
\text { to age- and population- } \\
\text { appropriate procedures. } \\
\text { Guardian permission as } \\
\text { a significant barrier to } \\
\text { research participation }\end{array}$ \\
\hline $\begin{array}{l}\text { Mack et al }{ }^{30} \\
\text { Country: Kenya and } \\
\text { South Africa }\end{array}$ & $\begin{array}{l}\text { Qualitative } \\
\text { study } \\
\text { Kenya (adults) } \\
\text { and South Africa } \\
\text { (adolescents and } \\
\text { young women) }\end{array}$ & $\begin{array}{l}\text { South Africa: } \\
\text { focus groups } \\
\text { ( } N=36 \\
\text { participants). } \\
\text { Two FGs with } \\
\text { adolescent aged } \\
\text { 14-17 years and } \\
\text { two with young } \\
\text { women aged } \\
\text { 18-24 years }\end{array}$ & $\begin{array}{l}\text { To explore the } \\
\text { potential role of choice } \\
\text { in women's use of HIV } \\
\text { prevention methods. } \\
\text { To present the analysis } \\
\text { of groups' attitudes } \\
\text { toward ARV-based HIV } \\
\text { prevention }\end{array}$ & $\begin{array}{l}\text { All focus groups } \\
\text { were audio-recorded, } \\
\text { transcribed, and translated } \\
\text { into English. } \\
\text { Transcripts were coded } \\
\text { using a codebook and } \\
\text { QSR NVivo } 9.0 \text { (QSR } \\
\text { International, Melbourne, } \\
\text { Australia); generated code } \\
\text { reports; and conducted } \\
\text { inductive thematic analysis } \\
\text { to identify major trends } \\
\text { and themes }\end{array}$ & $\begin{array}{l}\text { All groups expressed strong } \\
\text { interest in PrEP products. } \\
\text { Adolescent girls believed } \\
\text { that it would be possible to } \\
\text { obtain the products more } \\
\text { privately than condoms. } \\
\text { Some girls stated that they } \\
\text { would be interested in using } \\
\text { PrEP only after seeing other } \\
\text { girls use it. } \\
\text { Young women showed } \\
\text { concern that it would be } \\
\text { challenging to negotiate } \\
\text { PrEP use with a partner }\end{array}$ \\
\hline $\begin{array}{l}\text { Culp and Caucci }{ }^{28} \\
\text { Country: USA }\end{array}$ & $\begin{array}{l}\text { Analytic, } \\
\text { WestlawNext, } \\
\text { a subscription- } \\
\text { only online legal } \\
\text { research service }\end{array}$ & $\begin{array}{l}\text { A } 50 \text {-state } \\
\text { analysis of minor } \\
\text { consent laws and } \\
\text { its implications } \\
\text { for PrEP }\end{array}$ & $\begin{array}{l}\text { To analyze laws related } \\
\text { to a minor's ability to } \\
\text { consent to medical } \\
\text { care, including HIV } \\
\text { diagnostic testing and } \\
\text { treatment, and its } \\
\text { implications for PrEP }\end{array}$ & $\begin{array}{l}\text { Staff collected all statutes } \\
\text { and regulations about } \\
\text { an adolescent's ability to } \\
\text { consent to HIV diagnosis, } \\
\text { treatment, and prevention. } \\
\text { On laws current as of } \\
\text { December } 3 \mathrm{I}, 20 \mathrm{II}\end{array}$ & $\begin{array}{l}\text { Minors' access to PrEP } \\
\text { without parental consent is } \\
\text { unclear. } \\
\text { No state expressly prohibits } \\
\text { minors' access to PrEP. } \\
\text { All jurisdictions allow } \\
\text { adolescents to consent to } \\
\text { diagnosis and treatment } \\
\text { of STIs; only eight } \\
\text { jurisdictions allow consent } \\
\text { to prophylactic services }\end{array}$ \\
\hline $\begin{array}{l}\text { Clinical trial (ATN } \\
\text { I I } 3 \text { substudy) } \\
\text { Country: USA }\end{array}$ & $\begin{array}{l}\text { Qualitative } \\
\text { study }\end{array}$ & $\begin{array}{l}17 \text { research } \\
\text { personnel at } \\
\text { I3 ATN sites } \\
\text { considering } \\
\text { "implementation" } \\
\text { of ATN II3 }\end{array}$ & $\begin{array}{l}\text { To examine factors } \\
\text { related to the process } \\
\text { by which IRBs and } \\
\text { research personnel } \\
\text { made decisions } \\
\text { regarding whether to } \\
\text { approve and implement } \\
\text { the protocol. } \\
\text { Emphasis on the issue } \\
\text { of adolescent consent } \\
\text { with high-risk minor } \\
\text { participants }\end{array}$ & $\begin{array}{l}\text { Semi-structured interviews } \\
\text { and the receipt of IRB- } \\
\text { related correspondence } \\
\text { and documents generated } \\
\text { during the review process }\end{array}$ & $\begin{array}{l}\text { Of I3 ATN sites in } 12 \\
\text { states: seven received IRB } \\
\text { approval for ATN II } 3 \text {, } \\
\text { three were denied approval, } \\
\text { and three received no } \\
\text { formal IRB disposition }\end{array}$ \\
\hline
\end{tabular}

Abbreviations: ATN, Adolescent Medicine Trials Network; ARV, antiretroviral; FGs, focal groups; FTC, emtricitabine; IRBs, institutional review boards; PrEP, pre-exposure prophylaxis; SGMY, sexual and gender minority youth; SMS, short message service; STI, sexually transmitted infection; TDF, tenofovir disoproxil fumarate; 3MV, Many Men, Many Voices; YMSM, young men who have sex with men.

institutional review boards (IRB) on strategies to increase their research participation. Culp and $\mathrm{Caucci}^{28}$ analyzed laws regarding minor's ability to consent to medical care and its implications for PrEP. One substudy of ATN 113 examined frameworks implemented by IRBs and research personnel to decide whether a protocol would be accepted or not. In addition, an emphasis was placed on adolescent consent with high-risk minor participants. ${ }^{29}$

Finally, the study by Mack et $\mathrm{al}^{30}$ describes clinician attitudes toward, and practices around, PrEP use in youth.

Despite the encouraging results of PrEP trials in adults, their relevance to the realities of adolescents and young adults 


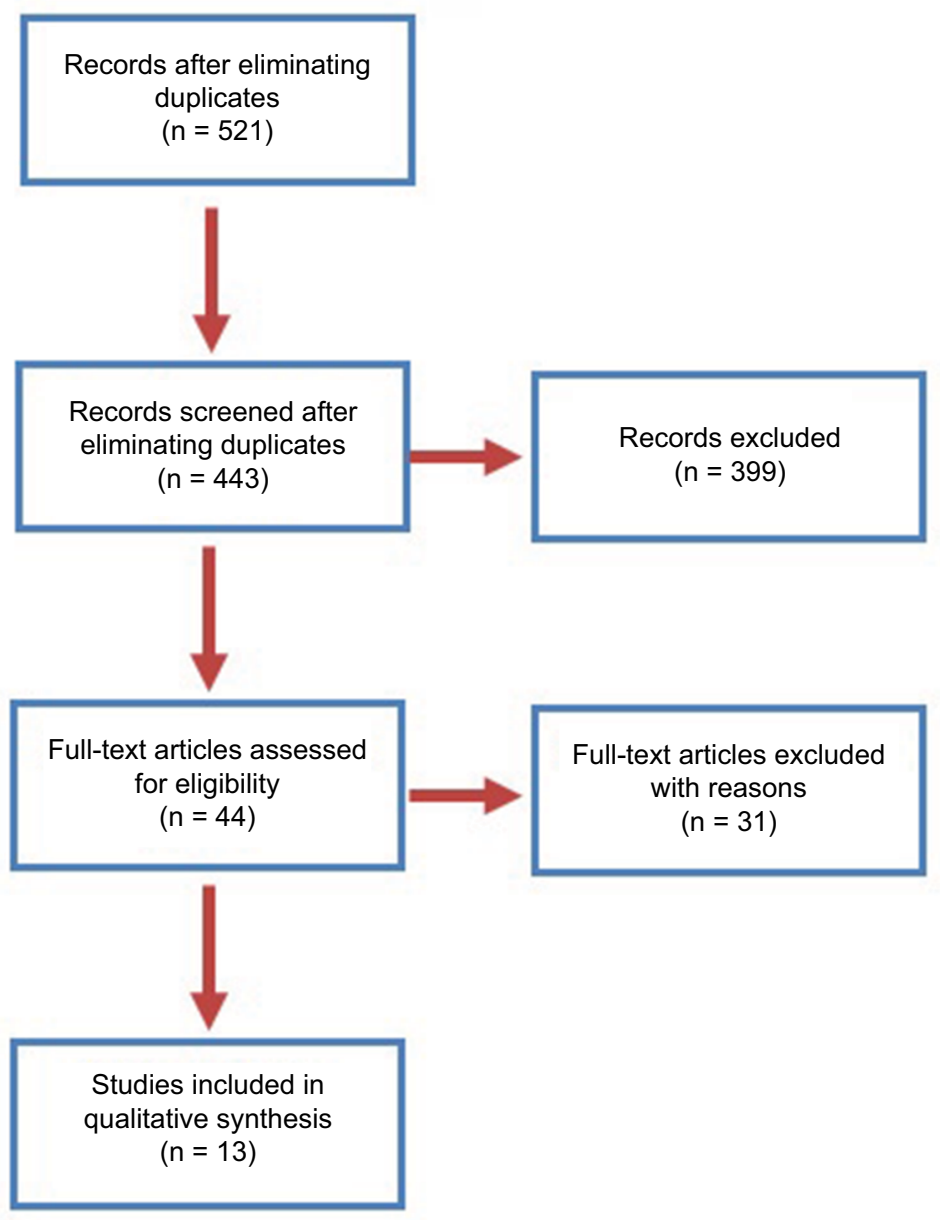

Figure I PRISMA flow diagram.

is not directly transferable. Thus, data from studies including youth and adolescents are critical for implementation of PrEP in such a highly vulnerable population.

At the time of this review, there were few PrEP studies among adolescents with available results. One such study, Project PrEPare (ATN protocol 113), ${ }^{19}$ was the first adolescent PrEP study among YMSM aged 15-17 years. Some findings of ATN 113 were initially presented at the Conference on Retroviruses and Opportunistic Infections (CROI). ${ }^{31}$

Two interconnected issues are important to highlight in this trial. The first is related to adherence: long-term, high adherence has proved to be essential for PrEP to be successful. Most of the adolescents participating in project PrEPare achieved protective drug levels during monthly visits, but adherence decreased when visits became quarterly. Among MSM aged 18-22 years, TDF in the plasma was detectable in only $20 \%$ of participants at week $24 .{ }^{21}$ In the follow-up study, $<34 \%$ had drug levels consistent with $4+$ pills/week at week $48 .{ }^{31}$ Such a finding is in contrast to adult trends seen in recent trials where adherence by drug detection was quantified at $51-100 \%{ }^{32}$

Other important findings relate to stigma as a barrier to effective health interventions. Adherent participants were significantly less likely than non-adherents to report concerns about what people would think when finding they were taking PrEP pills. They anticipated the perception of stigma, as living with HIV meant living with the fear and effects of stigmatization, with consequent social rejection, discrimination, or violence. ${ }^{33}$ Likewise, previous studies have shown that associating PrEP with sexual risk taking may reduce the motivation of young people to seek PrEP or to maintain PrEP use for fear of stigmatization. ${ }^{34,35}$ The process of enrolling adolescents in this trial was more time-consuming than in the parallel study group of 18-22 years (ATN protocol 110). ${ }^{36}$ The adolescents were allowed to provide self-consent to participate. This approach reduced by $50 \%$ the number of eligible sites cleared by their IRBs to be part of the study, as related in the qualitative substudy of ATN $113 .{ }^{29}$ 
The complexity of the legal, ethical, and practical barriers to conducting PrEP studies with adolescents are evident, as is the need for coherent and comprehensive standards for participation. ${ }^{28,29}$

The second trial, CHAMPS PillPlus (NCT02213328), included both male and female HIV-negative adolescents aged $16-19$ years..$^{20}$ Those under the age of 18 years had to obtain parental/guardian consent to participate in the study, but this requirement did not disturb the enrollment. Considering that adherence to daily medication regimens poses a significant challenge for adolescents, this study provided support using SMSs, adherence clubs, trained youth-friendly counselors, and real-time feedback on drug levels. A baseline analysis and early data from this study indicate a reasonable uptake and use of PrEP, based on initial plasma TDF levels. Those findings are encouraging, considering results from iPrEx indicating that PrEP reduced the risk of HIV infection by $92 \%$ in participants with detectable drug levels in plasma. ${ }^{9}$

Both ATN $113^{19}$ and CHAMPS ${ }^{20}$ trials showed a high level of acceptability to PrEP among YMSM, girls, and young women. Although some girls expressed hesitation with regard to PrEP, they appreciated the privacy of a pill and would be willing to take PrEP if it was provided for free in the USA. YMSM with better HIV knowledge and a higher level of education showed more interest and were more likely to take PrEP. Irrespective of prior knowledge, they expressed a desire for more information about this new prophylactic strategy. Prudent information for young PrEP users would include minimum necessary frequency of use and if gender would influence the overall dose to achieve similar levels of protection. ${ }^{38,39}$ Available data suggest that more consistent dosing is required to achieve sufficient levels of TDF in vaginal tissue when compared to rectal tissues. ${ }^{40}$ However, as demonstrated in the efficacy clinical trials of PrEP, women who were adherent to a daily PrEP regimen were strongly protected against HIV. ${ }^{10,11,41}$

Project PrEPare also demonstrated the feasibility of enrolling and retaining a young cohort of YMSM into a PrEP trial despite an intensive visit schedule. ${ }^{21}$ The data focus on YMSM and the general group of adolescents at risk for HIV infection. Nonetheless, the scientific health literature shows a lack of qualitative information on the attitudes and perceptions toward PrEP acceptability in other subgroups of adolescents such as intravenous drug users, transgender youth, adolescent sex workers, or teenagers in other cultural contexts.

Other ongoing, adolescent-inclusive trials hopefully will deliver more data to the discussion. One such study,
HPTN082, ${ }^{23}$ is focused on acceptance and adherence among adolescents and young women aged 16-25 years.

Haberer et $\mathrm{a}^{42}$ showed that scheduled SMS reminders improved highly active antiretroviral therapy (HAART) in the context of real-time monitoring in an adult population. The trial NCT02915367 is assessing the use of SMS reminders (a behavioral intervention) to improve medication compliance in young people. ${ }^{22} \mathrm{~A}$ better comprehension of useful indicators of adherence among adolescents at high risk for HIV infection is needed to ensure the effectiveness of PrEP programs.

Young people are not at uniform risk throughout adolescence, and PrEP does not need to be lifelong. As pointed by Hosek et al, ${ }^{21}$ "PrEP for young people may be best viewed as a time-limited strategy that can bridge the developmental period between sexual debut and adulthood." This idea may have a strong impact on acceptability and points out the difference between the use of PrEP and HAART for treatment.

Combining behavioral and biomedical approaches may be critical to successful implementation of PrEP programs among youth populations. One such trial, ATN 082, shows the feasibility of enrolling at-risk youth with behavioral intervention plus biomedical prevention (PrEP) with high acceptability; however, the self-reported pill adherence and corresponding plasma drug concentrations from participants were low. More optimistic findings, however, were the reduction in behavioral disinhibition with decrease in risky sexual behavior over time. ${ }^{21}$

One of the five studies included in the systematic review by Koechlin et $\mathrm{a}^{25}$ was not retrieved by our search strategy, so it does not appear individualized in Table 2. The adolescent girls showed interest in PrEP as protection from HIV, although a few participants appeared confused about if PrEP would protect them from pregnancy as well. ${ }^{30}$

One of the major concerns that could undermine PrEP benefits regarding risky sexual behavior is risk compensation, that is, PrEP could reduce condom use and increase the risk for other sexually transmitted infections (STIs) ${ }^{43-46}$ Rubtsova et $\mathrm{al}^{47}$ found that $20 \%$ of young women expected to use condoms less frequently if receiving PrEP. The data of adolescent girls from South Africa corroborate in part with this concern. They found PrEP particularly appealing because it would eliminate concerns about being seen while obtaining condoms from clinics. ${ }^{30}$ The use of condoms is closely related to exposure to partner violence. Even the fear of violence is linked to women's reluctance or inability to negotiate condoms or to use contraceptives. ${ }^{6}$ Indeed, if people were using condoms consistently, the rates of new HIV infections would not remain at 2 million new infections 
per year. ${ }^{48}$ On the other hand, there are studies showing no evidence of sexual risk compensation with daily oral PrEP; 49 Mugwanya et $\mathrm{al}^{50}$ encourage the assertion that behavior modifications, as a result of PrEP, may not undermine the public health benefits of PrEP.

Regarding risk perception, persons who perceive themselves at high risk for HIV infection have a higher PrEP uptake..$^{51}$ Adolescents and young people are known to have a lower perception of risk of being infected by HIV and other STIs. In Africa, young women have shown low HIV risk perception. ${ }^{52}$ The substudy of Crew 450 (YMSM aged 16-20 years) showed that unprotected anal intercourse had inversely proportional relationship with interest in taking PrEP. ${ }^{26}$

Regarding safety, several trials in the adult population demonstrated a small decrease in renal function and bone mineral density. ${ }^{53-56}$ However, if we consider that HIV infection would require lifelong antiretroviral therapy, with increased side effect burden, PrEP use might present a favorable risk-benefit ratio. Safety data in PrEP studies among adolescents were not available as of this writing.

Although there is a promising horizon for PrEP use among young people, use in this population may still present with several challenges. One of those challenges is acceptability of PrEP with health care providers: knowledge and confidence to prescribe PrEP remains limited among clinicians. ${ }^{57-59}$ Mullins et al ${ }^{59}$ specifically assessed the intention of clinicians to prescribe PrEP to adolescents. It is clear that, although all the participants highlight the role of PrEP as a strategy to diminish the risk of acquiring HIV infection, they are not unanimous in prescribing it for adolescents. Fewer participants reported intention to prescribe PrEP for adolescents, regardless of sexual orientation; many professionals identified a number of barriers for patients and providers, within the health care system and the community.

In high-incidence settings, access to PrEP could save money. With the ability to limit PrEP use to an identifiable risk period, we see increased cost savings as opposed to more expensive lifelong antiretroviral treatment. ${ }^{60}$

One study evaluated the laws referring to adolescent's ability to consent to diagnostic tests, treatment and prevention of HIV, and other STIs. ${ }^{28}$ The possibility of minors taking PrEP without parental consent is unclear in the studies, which may complicate efforts to provide clinical care to this age group. The Centers for Disease Control and Prevention PrEP guidelines recommend that all gaps in knowledge regarding this population are weighed against the potential benefit of providing PrEP for an individual adolescent at substantial risk for HIV infection. ${ }^{61}$ Clinicians considering providing PrEP to minors should observe the local laws and policies that may apply. ${ }^{25}$

Catalysts for success and barriers impacting acceptability and implementation of PrEP in adolescents are shown in Figure 2. Several topics will need to be better addressed for PrEP to become more widely available to youth at risk for HIV infection.

We faced difficulties when selecting a few studies for this review, because many of them did not consider particularities of each age group. The available data either did not distinguish specific adolescent years or are a part of several studies that focus on the adolescence period in question, which are still ongoing. Such studies will provide evidence to
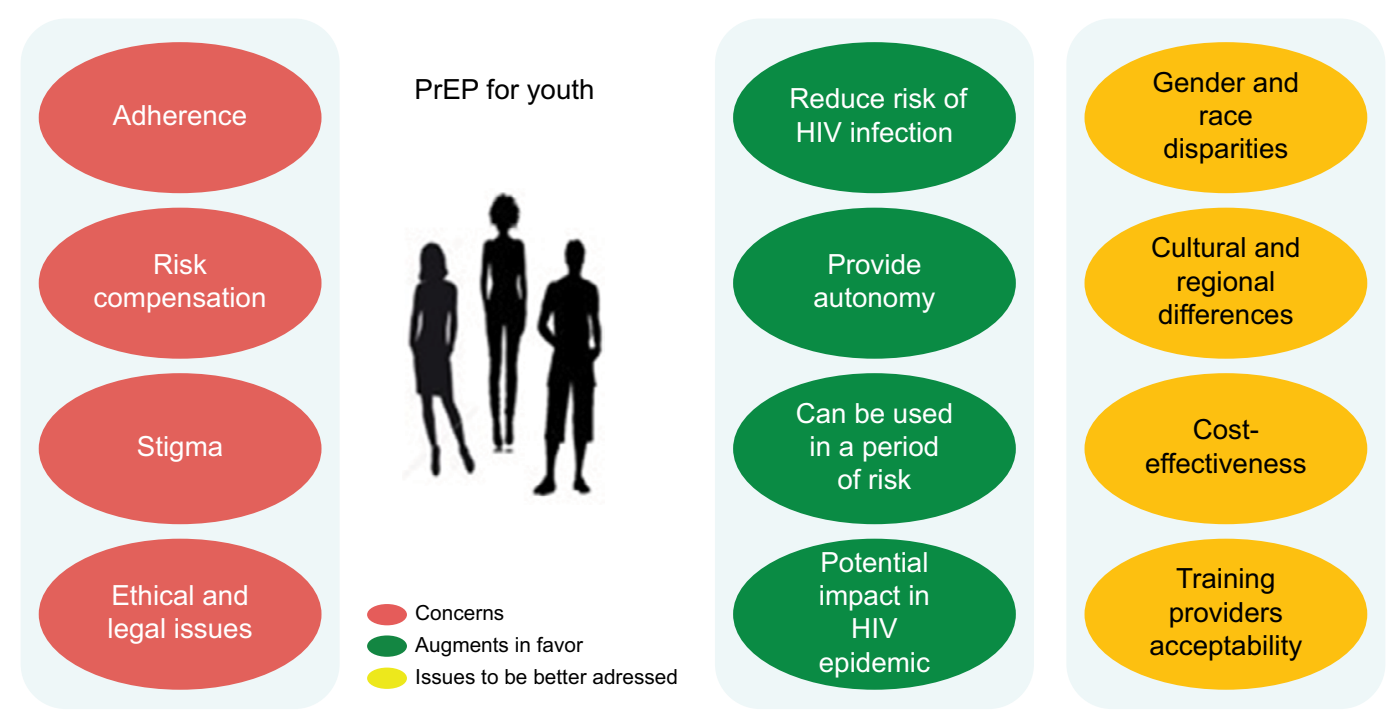

Figure 2 Factors that influence acceptability and implementation of PrEP in adolescents. Note: Arguments in favor and the issues that should be better addressed. Abbreviation: PrEP, pre-exposure prophylaxis. 
support sound decision making by health care professionals, aiming to not only protect individuals but also contribute to the control of the HIV pandemic.

Some argue that due to cost and adherence barriers, PrEP will not benefit those most in need and may actually enhance existing HIV-associated disparities. ${ }^{62}$

The inclusion of PrEP in public programs will require guidance to maximize impact and effectiveness based on region, population group, and individual risk. ${ }^{63}$ As Aggleton ${ }^{64}$ has remarked, "PrEP is an HIV prevention strategy that may be useful for some people in some contexts some of the time." It is clear that the benefits of PrEP will vary across different programs and global regions.

\section{Conclusion}

Oral PrEP offers an exciting opportunity for adolescents and young adults to access a new prevention option, respecting their particularities and vulnerabilities. Detailed information about the results of available studies should be adequately disseminated to both the youth population and their health care providers to facilitate effective and safe delivery of PrEP. Adherence to PrEP might be facilitated by technology, including SMS and wireless electronic monitoring, as well as counseling and adherence feedback (by measuring drug concentration when feasible. The focus should not be to use PrEP indefinitely, but rather to align PrEP use with periods of high risk for HIV infection. It is essential to reject stereotypes and sex-negative messaging in guiding decisions affecting PrEP access and uptake, since they may contribute to enhance stigma. Overall, it is evident that substantial more research is needed focusing on adolescents and PrEP.

Each country and program should research and understand the peculiar characteristics of their adolescent target populations - what they think, how they feel, and their perspectives surrounding PrEP and risky sexual behavior. With this information, policy makers and clinicians will be better equipped to serve and implement specific strategies that respond adequately to their health care needs.

\section{Disclosure}

The authors report no conflicts of interest in this work.

\section{References}

1. WHO. Health for the World's Adolescents: A Second Chance in the Second Decade. Geneva: World Health Organization; 2014.

2. WHO [webpage on the Internet]. Adolescents Falling through Gaps in HIV Services. Available from: http://www.who.int/mediacentre/news/ releases/2013/hiv-adolescents-20131125/en/. Accessed August 28, 2017.
3. Naswa S, Marfatia YS. Adolescent HIV/AIDS: issues and challenges. Indian J Sex Transm Dis. 2010;31(1):1-10.

4. Galvan A, Hare TA, Parra CE, et al. Earlier development of the accumbens relative to orbitofrontal cortex might underlie risk-taking behavior in adolescents. J Neurosci. 2006;26(25):6885-6892.

5. Galvan A, Hare T, Voss H, Glover G, Casey BJ. Risk-taking and the adolescent brain: who is at risk? Dev Sci. 2007;10(2):F8-F14.

6. UNAIDS [webpage on the Internet]. Get on the Fast-Track-The lifecycle approach to HIV; 2016. Available from: http://www.unaids.org/ en/resources/documents/2016/get-on-the-fast-track. Accessed August 28, 2017.

7. WHO [webpage on the Internet]. Sustainable Developmental Goals. Available from: http://www.un.org/sustainabledevelopment/sustainabledevelopment-goals/. Accessed August 28, 2017.

8. Flash C, Landovitz R, Giler RM, et al. Two years of Truvada for preexposure prophylaxis utilization in the US. J Int AIDS Soc. 2014;17(4 suppl 3):19730.

9. Grant RM, Lama JR, Anderson PL, et al; iPrEx Study Team. Preexposure chemoprophylaxis for HIV prevention in men who have sex with men. N Engl J Med. 2010;363(27):2587-2599.

10. Baeten JM, Donnell D, Ndase P, et al; Partners PrEP Study Team. Antiretroviral prophylaxis for HIV prevention in heterosexual men and women. N Engl J Med. 2012;367(5):399-410.

11. Choopanya K, Martin M, Suntharasamai P, et al. Antiretroviral prophylaxis for HIV infection in injecting drug users in Bangkok, Thailand (the Bangkok Tenofovir Study): a randomized, double-blind, placebocontrolled phase 3 trial. Lancet. 2013;381:2083-2090.

12. Van Damme L, Corneli A, Ahmed K, et al; FEM-PrEP Study Group. Preexposure prophylaxis for HIV infection among African women. N Engl J Med. 2012;367(5):411-422.

13. Marrazzo JM, Ramjee G, Richardson BA, et al; VOICE Study Team. Tenofovir-based preexposure prophylaxis for HIV infection among African women. $N$ Engl J Med. 2015;372(6):509-518.

14. McCormack S, Dunn DT, Desai M, et al. Pre-exposure prophylaxis to prevent the acquisition of HIV-1 infection (PROUD): effectiveness results from the pilot phase of a pragmatic open-label randomized trial. Lancet. 2016;387(10013):53-60.

15. Molina JM, Capitant C, Spire B, et al; ANRS IPERGAY Study Group. On-demand preexposure prophylaxis in men at high risk for HIV-1 infection. N Engl J Med. 2015;373(23):2237-2246.

16. WHO [webpage on the Internet]. Guidelines on When to Start Antiretroviral Therapy and Pre-Exposure Prophylaxis for HIV; 2015. Available from: www.who.int/hiv/pug/guidelines/earlyrelease-arv/en/. Accessed August 28, 2017.

17. WHO [webpage on the Internet]. Adolescence: A Period Needing Special Attention. Available from: http://apps.who.int/adolescent/seconddecade/section2/page1/recognizing-adolescence.html. Accessed August 28, 2017.

18. Ouzzani M, Hammady H, Fedorowicz Z, Elmagarmid A. Rayyan - a web and mobile app for systematic reviews. Syst Rev. 2016;5(1):210.

19. Westat. Project PrEPare - an open label demonstration project and phase II safety study of pre-exposure prophylaxis use among 15 to 17 year old young men who have sex with men (YMSM). Available from: https://clinicaltrials.gov/ct2/show/NCT01769456. NLM identifier: NCT01769456. Accessed August 28, 2017.

20. National Institute of Allergy and Infectious Diseases (NIAID). CHAMPS: choices for adolescent prevention methods for South Africa. Pilot Study B: 'PlusPills' a demonstration open label study to assess the acceptability and use of truvada pre-exposure prophylaxis in healthy, HIV-uninfected adolescents, 15-19 years of age. Available from: https://clinicaltrials.gov/ct2/show/NCT02213328. NLM identifier: NCT02213328. Accessed August 28, 2017.

21. Hosek S, Siberry G, Bell M, et al. Project PrEPare (ATN082): the acceptability and feasibility of an HIV pre-exposure prophylaxis (PrEP) trial with young men who have sex with men (YMSM). Acquir Immune Defic Syndr. 2013;62(4):447-456. 
22. Massachusetts General Hospital. Monitoring pre-exposure prophylaxis for young adult women (MPYA). Available from: https://clinicaltrials.gov/ct2/show/NCT02915367. NLM identifier: NCT02915367. Accessed August 28, 2017.

23. HPTN. Uptake and adherence to daily oral PrEP as a primary prevention strategy for young African women: A Vanguard Study. Available from: https://www.hptn.org/sites/default/files/2016-05/HPTN082_FINAL_ Protocol_12082015_0.pdf. Accessed August 28, 2017.

24. Duke University. Likely Use of PrEP for African American YMSM; 2016. Available from: https://clinicaltrials.gov/ct2/show/NCT02810249. NLM identifier: NCT02810249. Accessed August 28, 2017.

25. Koechlin FM, Fonner VA, Dalglish SL, et al. Values and preferences on the use of oral pre-exposure prophylaxis (PrEP) for HIV prevention among multiple populations: a systematic review of the literature. AIDS Behav. 2016;21(5):1325-1335.

26. Mustanski B, Johnson AK, Garofalo R, Ryan D, Birkett M. Perceived likelihood of using HIV pre-exposure prophylaxis medications among young men who have sex with men. AIDS Behav. 2013;17(6):2173-2179.

27. Fisher CB, Arbeit MR, Dumont MS, Macapagal K, Mustanski B. Self-consent for HIV prevention research involving sexual and gender minority youth: reducing barriers through evidence-based ethics. J Empir Res Hum Res Ethics. 2016;11(1):3-14.

28. Culp L, Caucci L. State adolescent consent laws and implications for HIV pre-exposure prophylaxis. Am J Prev Med. 2013;44(1S2):S119-S112.

29. Gilbert AL, Knopf AS, Fortenberry JD, Hosek SG, Kapogiannis BG, Zimet GD. Adolescent self consent for biomedical human immunodeficiency virus prevention. Res J Adolesc Health. 2015;57(1):113-119.

30. Mack N, Evens EM, Tolley EE, et al. Importance of choice in the rollout of ARV-based prevention to user groups in Kenya and South Africa: a qualitative study. J Int AIDS Soc. 2014;17(suppl 2):19157.

31. Hosek S, Rudy B, Landovitz R, et al. An HIV pre-exposure prophylaxis demonstration project and safety study for young men who have sex with men in the United States (ATN 110). J Int AIDS Soc. 2015;18:20479.

32. Haberer JE. Current concepts for PrEP adherence in the PrEP revolution: from clinical trials to routine practice. Curr Opin HIV AIDS. 2016;11(1):10-17.

33. Sandelowski M, Lambe C, Barroso J. Stigma in HIV-positive women. J Nurs Scholarsh. 2004;36(2):122-128.

34. Auerbach JD, Kinsky S, Brown G, Vignetta C. Knowledge, attitudes, and likelihood of pre-exposure prophylaxis (PrEP) use among US women at risk of acquiring HIV. AIDS Patient Care STDS. 2015;29(2):102-110.

35. Liu A, Cohen S, Follansbee S, et al. Early experiences implementing preexposure prophylaxis (PrEP) for HIV prevention in San Francisco. PLoS Med. 2014;11(3):e1001613.

36. Hosek SG, Rudy B, Landovitz R, et al; Adolescent Trials Network (ATN) for HIVAIDS Interventions. An HIV preexposure prophylaxis demonstration project and safety study for young MSM. J Acquir Immune Defic Syndr. 2017;74(1):21-29.

37. Gill K, Marcus R, Dietrich J, et al [webpage on the Internet]. An analysis of baseline and early data from the Plus Pill study: an open -label trial of preexposure prophylaxis for South African adolescents. In: International AIDS Conference; July 19, 2016; Durban. Available from: http://www. jiasociety.org/index.php/jias/article/view/21107/html. Accessed August $28,2017$.

38. Hendrix CW. Exploring concentration response in HIV preexposure prophylaxis to optimize clinical care and trial design. Cell. 2013;155(3):515-518.

39. Cottrell ML, Yang KH, Prince HMA, et al. Predicting effective Truvada PrEP dosing strategies with a novel PK-PD model incorporating tissue active metabolites and endogenous nucleotides (EN). OA22.06 LB. AIDS Res Hum Retrovirus. 2014;30(S1):30.

40. Cottrell ML, Srinivas N, Kashuba AD. Pharmacokinetics of antiretrovirals in mucosal tissue. Expert Opin Drug Metab Toxicol. 2015;11(6):893-905.

41. Thigpen MC, Kebaabetswe PM, Paxton LA, et al; TDF2 Study Group. Antiretroviral preexposure prophylaxis for heterosexual HIV transmission in Botswana. N Engl J Med. 2012;367(5):423-434.
42. Haberer JE, Musinguzi N, Tsai AC, et al. Real-time electronic adherence monitoring plus follow-up improves adherence compared with standard electronic adherence monitoring. AIDS. 2017;31(1):169-171.

43. Cassell MM, Halperin DT, Shelton JD, Stanton D. Risk compensation: the Achilles' heel of innovations in HIV prevention? BMJ. 2006;332(7541):605-607.

44. Eaton LA, Kalichman S. Risk compensation in HIV prevention: implications for vaccines, microbicides, and other biomedical HIV prevention technologies. Curr HIV/AIDS Rep. 2007;4(4):165-172.

45. Hogben M, Liddon N. Disinhibition and risk compensation: scope, definitions, and perspective. Sex Transm Dis. 2008;35(12): 1009-1010.

46. Underhill K, Mayer KH. Sexual behaviour among users of antiretroviral pre-exposure prophylaxis. Lancet Infect Dis. 2013;13(12):996-997.

47. Rubtsova A, Wingood GM, Dunkle K, Camp C, DiClemente RJ. Young adult women and correlates of potential adoption of pre-exposure prophylaxis (PrEP): results of a national survey. Curr HIV Res. 2013;11(7): 543.

48. UNAIDS. AIDS info [homepage on the Internet]. Available from: http:// aidsinfo.unaids.org/. Accessed August 28, 2017.

49. Marcus JL, Glidden DV, Mayer KH, et al. No evidence of sexual risk compensation in the iPrEx trial of daily oral HIV preexposure prophylaxis. PLoS One. 2013;8(12):e81997.

50. Mugwanya KK, Donnell D, Celum C, et al; Partners PrEP Study Team. Sexual behaviour of heterosexual men and women receiving antiretroviral pre-exposure prophylaxis for HIV prevention: a longitudinal analysis. Lancet Infect Dis. 2013;13(12):1021-1028.

51. Grant RM, Anderson PL, McMahan V, et al; iPrEx Study Team. Uptake of pre-exposure prophylaxis, sexual practices, and HIV incidence in men and transgender women who have sex with men: a cohort study. Lancet Infect Dis. 2014;14(9):820-829.

52. UNAIDS 2016 | GUIDANCE. Putting HIV Prevention among Adolescent Girls and Young Women on the Fast-Track and Engaging Men and Boys. Available from: http://www.unaids.org/sites/default/files/ media_asset/UNAIDS_HIV_prevention_among_adolescent_girls_and_ young_women.pdf. Accessed August 28, 2017.

53. Martin M, Vanichseni S, Suntharasamai $P$, et al. Renal function of participants in the Bangkok tenofovir study-Thailand, 2005-2012. Clin Infect Dis. 2014;59(5):716-724.

54. Solomon MM, Lama JR, Glidden DV, et al; iPrEx Study Team. Changes in renal function associated with oral emtricitabine/tenofovir disoproxil fumarate use for HIV pre-exposure prophylaxis. AIDS. 2014;28(6):851-859.

55. Kasonde M, Niska RW, Rose C, et al. Bone mineral density changes among HIV-uninfected young adults in a randomised trial of preexposure prophylaxis with tenofovir-emtricitabine or placebo in Botswana. PLoS One. 2014;9(3):e90111.

56. Mirembe BG, Kelly CW, Mgodi N, et al. Bone mineral density changes among young, healthy African women receiving oral tenofovir for HIV preexposure prophylaxis. J Acquir Immune Dec Syndr. 2016;71:287-294.

57. Mimiaga MJ, White JM, Krakower DS, Biello KB, Mayer KH. Suboptimal awareness and comprehension of published pre-exposure prophylaxis efficacy results among physicians in Massachusetts. AIDS Care. 2014;26(6):684-693.

58. Karris MY, Beekmann SE, Mehta SR, Anderson CM, Polgreen PM. Are we prepped for preexposure prophylaxis (PrEP)? Provider opinions on the real-world use of PrEP in the United States and Canada. Clin Infect Dis. 2014;58(5):704-712.

59. Mullins TL, Lally M, Zimet G, Kahn JA; Adolescent Medicine Trials Network for HIV/AIDS Interventions. Attitudes toward CDC interim pre-exposure prophylaxis (PrEP) guidance and operationalizing PrEP for adolescents. AIDS Patient Care STDS. 2015;29(4):193-203.

60. Walensky RP, Park JE, Wood R, et al. The cost-effectiveness of preexposure prophylaxis for HIV infection in South African women. Clin Infect Dis. 2012;54(10):1504-1513. 
61. CDC. Preexposure Prophylaxis for the Prevention of HIV Infection in the United States - 2014. Clinical Practice Guideline. Available from: https:// www.cdc.gov/hiv/pdf/prepguidelines2014.pdf. Accessed August 28, 2017.

62. Curran JW, Crosby RA. Pre-exposure prophylaxis for HIV: who will benefit and what are the challenges? Am JPrev Med.2013;44(1 suppl 2): S163-S166.
63. Cáceres CF, Mayer KH, Baggaley R, O'Reilly KR. PrEP implementation science: state-of-the-art and research agenda. J Int AIDS Soc. 2015; 18(4Suppl 3):20527.

64. Aggleton P. Social research and the response to HIV: legacy and future. In: CSRH-ARCSHS AIDS 2014 Symposium; July 18, 2014; Melbourne, Australia.

\section{Publish your work in this journal}

Adolescent Health, Medicine and Therapeutics is an international, peer-reviewed, open access journal focusing on health, pathology, and treatment issues specific to the adolescent age group. All aspects of health maintenance, preventative measures and disease treatment interventions are addressed within the journal and practitioners from all disciplines are invited to submit their work as well as healthcare researchers and patient support groups. This journal is included in PubMed. The manuscript management system is completely online and includes a very quick and fair peer-review system. Visit http://www.dovepress.com/testimonials. php to read real quotes from published authors.

Submit your manuscript here: http://www.dovepress.com/adolescent-health-medicine-and-therapeutics-journal 